\title{
HOT, COLD, WET, AND DRY HUTAYMAH ULTRAMAFIC INCLUSIONS: A RECORD OF MANTLE MAGMATISM BENEATH THE ARABIAN SHIELD AND FLANKING THE RED SEA RIFT.
}

Thornber, C.R.

\author{
U.S. Geological Survey, MS 903, DFC, Denver, CO 80225 USA.
}

Harrat Hutaymah is the youngest, smallest and most isolated of the Cenozoic mafic alkaline volcanic fields (harrats) of Arabia. Situated farthest off the flank of the Red Sea rift at the northeastern margin of the uplifted and exposed Arabian Shield (lat $27^{\circ} \mathrm{N}$., long $42^{\circ} \mathrm{E}$.), Hutaymah is unique among Arabian harrats in that it is diatreme dominated and xenolith rich. Inclusions sample a variety of ultramafic rock types that occur deep within and beneath the $\sim 40-\mathrm{km}$-thick Proterozoic crust. A comprehensive suite of 713 Hutaymah ultramafic xenoliths and megacrysts comprises $31 \%$ spinel peridotite; $57 \%$ pyroxenite and $12 \%$ amphibolite, and includes $2 \%$ peridotite in contact with either pyroxenite or amphibolite. Petrographic study of 430 polished thin sections, 985 microprobe analyses of minerals in 193 samples, and 68 whole rock analyses allow subdivision of the traditional $\mathrm{Cr}$-diopside (Type I) and Al-augite (Type II) groups of ultramafic xenoliths into three broad categories of anhydrous inclusions ("dry" rocks): (1) Al-Fe-Ti-rich to $\mathrm{Mg}-\mathrm{Cr}$-rich igneous pyroxenite; (2) $\mathrm{Al}-\mathrm{Fe}-\mathrm{Ti}-\mathrm{rich}$ to $\mathrm{Mg}-\mathrm{Cr}-\mathrm{rich}$ metamorphic pyroxenite; and (3) $\mathrm{Mg}-\mathrm{Cr}$ rich peridotite ( \pm partial melt). Less abundant hydrous equivalents of these groups ("wet" rocks) include kaersutite-bearing Al-Fe-Ti-rich igneous pyroxenite and amphibolite, and pargasite- and phlogopite-bearing $\mathrm{Mg}-\mathrm{Cr}$-rich peridotite and metamorphic pyroxenite. Among the main categories of anhydrous and hydrous inclusions, 26 ultramafic rock types were identified (Table 1). In general terms, the variety of ultramafic rocks reflects the heterogeneity within the approximate depth range of spinel lherzolite stability and in the path of ascending Quaternary/Tertiary mafic alkaline magmas.

As used herein, "hot" inclusions have relatively high pyroxene equilibration temperatures $\left(1000-1150^{\circ} \mathrm{C}\right)$ (Wells, 1977) and textures, modal mineralogy, and mineral compostions that reflect primary igneous crystallization, high temperature deformation, or partial melting. These samples illustrate the effects of injection and dynamic crystallization of host-related mafic alkaline magma and the complementary effects of heating, fluid infiltration and partial melting of surrounding mantle lherzolite. "Cold" inclusions have relatively low pyroxene equilibration temperatures $\left(<950^{\circ} \mathrm{C}\right)$, and textures, modal mineralogy and mineral chemistry, that reflect metamorphic annealing, recrystallization and deformation during cooling. Similar bulk rock and mineral compositional trends and gradational textural and modal characteristics between "hot" rocks of igneous origin and their "cold" metamorphic counterparts reflect either Proterozoic or precursory Cenozoic episodes of deep alkaline magmatism. The ratio of $\mathrm{Al}+\mathrm{Na}+\mathrm{Fe}+\mathrm{Ti} / \mathrm{Mg}+\mathrm{Cr}$ in pyroxenes (plotted vs $\mathrm{Ca}$ content of clinopyroxene in figure 1) is used here as an index of alkali basaltic components relative to the refractory (or residual) components of mantle peridotite.

\section{ANHYDROUS IGNEOUS PYROXENITES}

"Hot"and "dry" pyroxenites comprise $36 \%$ of the Hutaymah suite and exhibit a continuous compositional array from rare Fe-rich clinopyroxenite (khaki green), through common AlFe-Ti-rich varieties (black), to less abundant $\mathrm{Mg}-\mathrm{Cr}$-rich clinopyroxenite (dark green). This entire group is distinguished by clinopyroxene (cpx) having a low Ca content (Figure 1). Where present, orthopyroxene (opx) has a complementary high-Ca content and yields high two-pyroxene equilibration temperatures $\left(1000-1150^{\circ} \mathrm{C}\right)$.

Al-Fe-Ti-rich cumulus clinopyroxenite (including cpx megacrysts), websterite and wehrlite are compositionally similar to the magmatic $c p x, c p x-o p x$ or $c p x$-olivine assemblages crystallized experimentally from alkali basaltic liquids over a pressure range equivalent to a depth interval of $\sim 70-\sim 30 \mathrm{~km}$, which also corresponds to that of spinel lherzolite stability. Igneous crystallization over this entire depth range is indicated by composite clinopyroxenite and spinel lherzolite xenoliths; however, because there is no primary (igneous) garnet $(>70 \mathrm{~km})$ and there are numerous samples containing only $\mathrm{cpx}(70-50 \mathrm{~km})$, it is possible that the entire Al-Fe-Ti-rich magmatic suite was sampled from within \pm 10 $\mathrm{km}$ of the base of the $40-\mathrm{km}$-thick crust.

$\mathrm{Mg}-\mathrm{Cr}$-rich igneous clinopyroxenites, except for rare megacrysts, are all composed of allotriomorphic- to hypidiomorphic granular cpx, which is frequently twinned and (in some samples) encloses olivine to produce heteradcumulus textures. A striking feature of coarse-grained samples is symplectitic to poikilitic cpx-opx intergrowth. This hightemperature recrystallization process reflects near-solidus (synmagmatic?) deformation in the presence of a fluid phase (Boland and Otten, 1985). The Al+Na+Fe+Ti/Mg+Cr and 
low-Ca clinopyroxene signature of "hot" $\mathrm{Mg}-\mathrm{Cr}-$ - $\mathrm{cich}$ pyroxenites is transitional between that of partial-melt-bearing $\mathrm{Mg}$-Cr-rich peridotite and $\mathrm{Al}-\mathrm{Fe}-\mathrm{Ti}$-rich cumulates (Figure 1 ), and suggests primary crystallization from mixtures of alkali basaltic magma and melted lherzolitic wall-rock. This interpretation is supported by the association of these three varieties of "hot" inclusions within sample suites from individual localities.

\section{ANHYDROUS METAMORPHIC PYROXENITES}

"Cold" and "dry" metamorphic pyroxenites comprise $21 \%$ of the Hutaymah suite and, similar to "hot" pyroxenites, exhibit a continuous compositional range from Al-Fe-Ti-rich pyroxenites (black) to $\mathrm{Mg}-\mathrm{Cr}$-rich pyroxenites (emerald green). Petrogenesis of this group is attributed to processes of in situ annealing, subsolidus recrystallization and deformation during cooling of igneous pyroxenite at variable depths. These metamorphic rocks all have $\mathrm{Ca}-$ rich $\mathrm{cpx}$ and $\mathrm{Ca}$-poor opx and corresponding low temperatures of equilibration $\left(<950^{\circ} \mathrm{C}\right)$ relative to their igneous counterparts (Figure 1, Table 1). The range in $\mathrm{Al}+\mathrm{Na}+\mathrm{Fe}+\mathrm{Ti} / \mathrm{Mg}+\mathrm{Cr}$ of pyroxene is generally consistent with that of bulk-rock chemistry in this group and is comparable to the range observed in igneous pyroxenites (Figure 1).

Among the Al-Fe-Ti-rich metamorphic samples there is complete textural gradation between equigranular to granular spinel-free orthopyroxenite and websterite, green-spinel websterite ( \pm plagioclase, olivine, sapphirine, and garnet), and porphyroblastic-granular garnet pyroxenite. Less deformed variants within this group provide textural hints of an igneous origin including centimeter-scale igneous layering, annealed (relict) cumulus textures and intrusive veining of peridotite. Some websterites of the Al-Fe-Ti-rich group ( \pm olivine and including some veins in peridotite) have higher $\mathrm{Mg} / \mathrm{Fe}$ pyroxene compostions, relative to their igneous counterparts that indicate pre-metamorphic crystallization from either primitive alkaline basalt or a magma mixed with melted lherzolite. Pyroxene $\mathrm{Al}+\mathrm{Ti}$ concentrations in this group are all higher than in $\mathrm{Mg}-\mathrm{Cr}$-rich metamorphic pyroxenites and differ from igneous equivalents in a manner consistent with pyroxene subsolidus exsolution and intergranular garnet-forming reactions.

Thermobarometry of garnet bearing samples (Wells, 1977; Wood, 1974), and available experimental evidence (e.g., Irving, 1974) indicate isobaric cooling and recrystallization of alkali-basalt fractionates over a depth range of 33-40 km, and provide evidence for prehost-volcanic (and possibly Proterzoic) magmatic underplating of the crust.

$\mathrm{Mg}-\mathrm{Cr}$-rich metamorphic pyroxenites include clinopyroxenite, websterite, olivine websterite and orthopyroxenite. Coarsely exsolved $\mathrm{Cr}-\mathrm{Mg}$-rich $\mathrm{cpx}$ megacrysts exhibit compositional and textural gradation with equigranular varieties of websterite and olivine websterite (one large websterite sample has a megacrystic core). Websterite ( \pm olivine) also occurs as discrete samples, as concordant layers in foliated peridotite or as intrusive veinlets in porphyroclastic peridotite. $\mathrm{Mg}-\mathrm{Cr}$-rich metamorphic pyroxenites have higher $\mathrm{Al}+\mathrm{Na}+\mathrm{Fe}+\mathrm{Ti} / \mathrm{Mg}+\mathrm{Cr}$ pyroxene than similar high-Ca cpx and low-Ca opx of "cold" porphyroclastic lherzolite and overlapping those of "cold" foliated and equigranular lherzolite (Figure 1). This signature of enrichment in alkali basaltic components is comparable to that of "hot" (partial-melt-bearing) peridotite and $\mathrm{Mg}-\mathrm{Cr}$-rich igneous pyroxenite. $\mathrm{Mg}-\mathrm{Cr}$-rich metamorphic pyroxenites are interpreted to have crystallized from either mixed melts, generated within lherzolite adjacent to basaltic magma, or in situ. melting of enriched (hydrous?) lherzolite mantle. In either case, the relic igneous origin is masked by subsequent cooling and textural and chemical equilibration with surrounding peridotite.

\section{ANHYDROUS PERIDOTITES}

"Hot" and "cold" Mg-Cr-rich "dry" peridotites are characterized by the presence or absence of intra- and inter-granular partial melt. There are two categories of anhydrous nonmelted lherzolites, protogranular to porphyroclastic and foliated to equigranular (Table 1). Both have low-temperature pyroxene chemistry $\left(800-900^{\circ} \mathrm{C}\right)$ and non-reacted grain boundary interfaces, and there is complete textural gradation within and between them. The latter category of deformed and recrystallized lherzolite has a higher modal abundance of pyroxene having higher $\mathrm{Al}+\mathrm{Na}+\mathrm{Fe}+\mathrm{Ti} / \mathrm{Mg}+\mathrm{Cr}$, overlapping that of $\mathrm{Mg}-\mathrm{Cr}-\mathrm{rich}$ metamorphic pyroxenite (Figure 1). Some relict porphyroclastic samples include neoblastic zones in gradational contact with concordant layers of $\mathrm{Mg}-\mathrm{Cr}$-rich metamorphic pyroxenite. These samples are the "frozen" record of a process involving melting, internal mobilization and recrystallization of preexisting lherzolite. Partial-melt-bearing peridotites provide "hot" examples of this process in the "active" magma/mantle system.

"Hot" peridotites are porphyroclastic to foliated, disruptive and fluoidal. This group ranges to relatively high temperature $\left(<950-1100^{\circ} \mathrm{C}\right)$, and low-Ca cpx, high Ca-opx and has $\mathrm{Al}+\mathrm{Na}+\mathrm{Fe}+\mathrm{Ti} / \mathrm{Mg}+\mathrm{Cr}$ enriched pyroxene compositions that overlap those of $\mathrm{Mg}-\mathrm{Cr}-\mathrm{rich}$ igneous pyroxenites (collected at the same localities) (Figure 1). An interpretation of melting and component exchange between peridotitic wall-rock and adjacent alkaline magma is best exemplified by $\mathrm{Mg}-\mathrm{Cr}$-rich wehrlites, which are composed of lherzolitic olivine porphyroclasts amidst igneous clinopyroxene. 


\section{HYDROUS INCLUSIONS}

By analogy with their "dry" equivalents, "wet" inclusions range from "hot" to "cold" varieties. Pyroxenes, where present, exhibit a similar range in chemistry (Figure 1). Pargasite- or phlogopite-bearing $\mathrm{Mg}-\mathrm{Cr}$ rich pyroxenite and peridotite are found only at localities with abundant kaersutitic megacrysts or amphibolites (including kaersutite in contact with peridotite) and are thus correlated with primary hydrous alkaline magmatism. Discrete and composite association of hydrous inclusions and partial-melt-bearing peridotite suggests solidus depression within "cold" and "dry" spinel lherzolite mantle affected by metasomatism involving $\mathrm{H}_{2} \mathrm{O}$-rich magmatic fluids. The extent to which such fluids may have been generated by magmatic interaction with preexisting amphibolespinel-lherzolite remains enigmatic.

Table 1: $\mathrm{Mg}-\mathrm{Cr}$-rich and $\mathrm{Al}-\mathrm{Fe}-\mathrm{Ti}-$ rich Hutaymah ultramafic rock types (symbols shown are used in Figure 1).

\begin{tabular}{|c|c|}
\hline 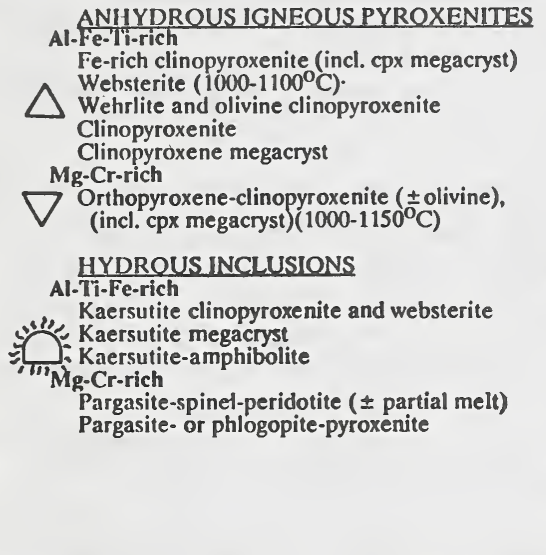 & $\begin{array}{l}\text { ANHYPROUS METAMORPHIC PYROXENITES } \\
\text { AN-Fe-Ti-rich } \\
\text { Websterite (spinel free) }\left(800-850^{\circ} \mathrm{C}\right) \\
\text { Orthopyroxenite (spinel free) }\left(800-850^{\circ} \mathrm{C}\right) \\
\text { Green-spinel websterite }\left( \pm \text { sapphirine) }\left(750-850^{\circ} \mathrm{C}\right)\right. \\
\text { Green-spinel olivine websterite }\left(840-940^{\circ} \mathrm{C}\right) \\
\text { Green-spinel plagioclase websterite }\left(800^{\circ} \mathrm{C}\right) \\
\text { Green-spinel garnet pyroxenite }\left(700-850^{\circ} \mathrm{C}\right) \\
\text { Garnet pyroxenite (spinel free) }\left(700-850^{\circ} \mathrm{C}\right) \\
\text { Mg-Cr-rich. } \\
\text { Orthopyroxenite (incl. opx megacryst) }\left(770-950^{\circ} \mathrm{C}\right) \\
\text { Olivine websterite }\left(850-950^{\circ} \mathrm{C}\right) \\
\text { Websterite and clinopyroxenite }\left(750-950^{\circ} \mathrm{C}\right) \\
\text { Clinopyroxene megacryst (exsolved-relict) }\left(900^{\circ} \mathrm{C}\right) \\
\text { ANHYDROUS PERIDOTITE } \\
\text { Mg-Cr-rich } \\
\text { Protogranular-porphyroclastic lherzolite }(800-8700 \mathrm{C}) \\
\text { Foliated-equigranular lherzolite }(870-9000 \mathrm{C}) \\
\text { Partial-melt-bearing peridotite: } \\
\text { Wherzolite and harzburgite }\left(950-1100^{\circ} \mathrm{C}\right) \\
\text { Wehrlite }\end{array}$ \\
\hline
\end{tabular}

Figure 1: Average clinopyroxene core compositions from different samples; grouped as listed in Table 1 (p.f.u. = pyroxene formulae units).

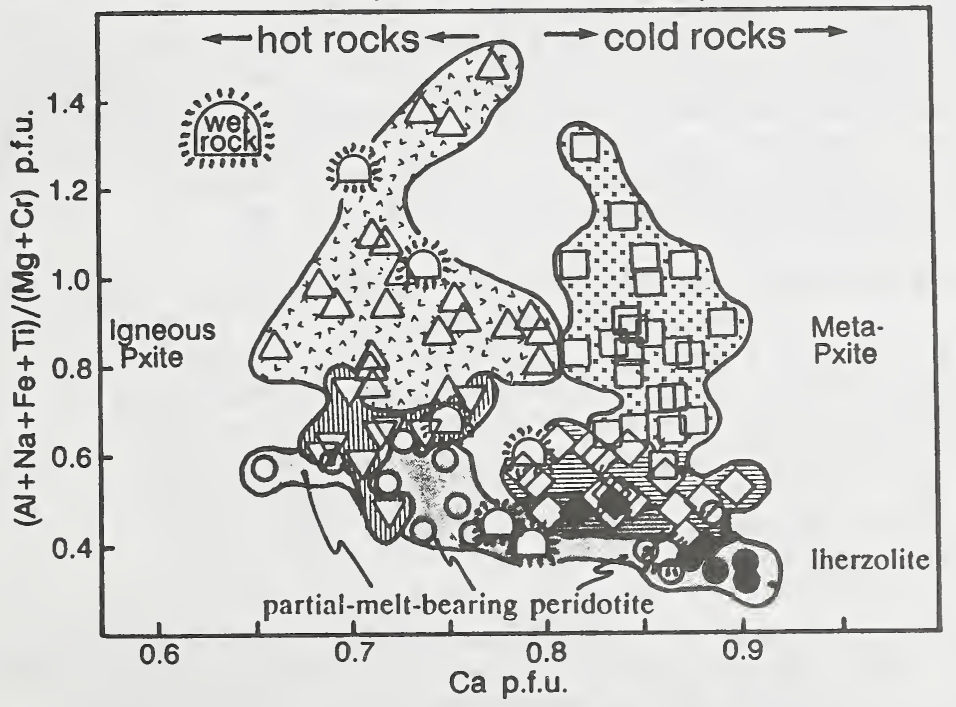

REFERENCES

Boland and Otten (1985) Symplectitic augite, evidence for discontinuous preciptitation as an exsolution mechanism in Ca-rich clinopyroxene, Journal of Metamorphic Geology, 3, 13-20.

Irving, A.J. (1974) Geochemical and high pressure experimental studies of garnet pyroxenite and pyroxene granulite xenoliths from the Delegate basaltic pipes, Australia, Journal of Petrology, 15, 1-40.

Wells, P.R.A. (1977) Pyroxene thermometry in simple and complex systems, Contributions to Mineralogy and Petrology, 62, 129-139.

Wood, B.J.(1974) The solubility of alumina in orthopyroxene coexisting with garnet, Contributions to Mineralogy and Petrology, 46, 1-15. 